\title{
Therapeutic Potential of Whey against Aging Related Cytological Damage of Adenohypophysis of Rat
}

Norhan TAH Kandil ${ }^{1}$, Dalia AM Sabry ${ }^{1}$, Nermin EE Ashry ${ }^{1}$ and Hassan IH El-Sayyad ${ }^{1}$

${ }^{1}$ Zoology Department, Faculty of Science, Mansoura University, Egypt

Article History
Received: 27.08 .2020
Accepted: 13.09 .2020
Published: 30.09 .2020
Journal homepage:
http://www.easpublisher.com/easjals/
Quick Response Code

Abstract: Aging has resulted in dramatic effects on body organs and development of
metabolic diseases with suspected origin from defects of gonads. The research is to
examine the aging related changes of cytological framework of the pituitary
adenohypophysis and demonstrate the antiaging effects of supplementation of whey.
Eight and 30-months old rats were divided into two main groups with or without whey
supplementation (n=4). Whey supplementation was carried out every other day for two
months. This was accompanied by euthanization and dissection of pituitary gland,
fixation in phosphate buffered osmium tetraoxide and processed for transmission
electron microscopic examination. Whey supplementation of 8 moth-old rats maintained
the secretory function of somatotroph and gonadotroph cells. However, old rats (30
month old) possessed edematous lesions in sommatotroph and gonadotroph cells with
degranulation of secretory granules. Congestion of blood capillaries and accumulation of
fat globules were observed. Whey supplementation to old rats improved the
cytopathological changes and restored the accumulation of secretory granules. The
capacity of whey supplementation to restore the secretory function of sommatotroph and
gonadotroph cells that are responsible for the secretion of growth hormone and
testosterone and follicle stimulating hormone that decrease the aging related
development of diseases.
Keywords: Ageing, Somatotrophs, Gonadotrophs, Whey.

Copyright $\left({ }_{0} 2020\right.$ The Author(s): This is an open-access article distributed under the terms of the Creative Commons Attribution 4.0 International License (CC BY-NC 4.0) which permits unrestricted use, distribution, and reproduction in any medium for non-commercial use provided the original author and source are credited.

\section{INTRODUCTION}

Ageing is a biological process involving programmed loss of fitness, indicated by epigenetic alterations that decrease cell function (Speakman et al., 2004). Aging interfered with altering the hypothalamicpituitary-testicular axis resulting in the hypogonadism and decrease of testosterone secretion (Feldman et al., 1994, Andre and Gary, 2011) and reduction of Leydig cells (Almeida et al., 2017).

It is known that growth hormone is the promotor of circulating levels of IGF-1 and consequently promoting insulin secretion and regulating cellular activities (Yuan et al., 2008). Inhibition of growth hormone and insulin growth factor-1 signaling in old individual led to marked loss of tissue structure and function (Ashpole et al., 1997). Dietary restriction also, interfered with growth hormone and insulin growth factor-1 genes along with increased body weight gain and body fat, reduced size of muscle and its activity and decreased concentrations of androgen and estrogen hormones resulting in development of aging related break-down of body organs (Veldhuis et al., 1997; Boguszewski et al., 2005; Moro et al., 2016).
Genes Inactivation affecting the growth hormone / IGF1 signalling promoting hyperglycemia and hyperinsulinemia are essential factors in aging (Anisimov and Bartke, 2013).

Also, aging may impair the release of ovarian hormones through reduction of the central neurotransmitter activity managing gonadotropin secretion (Rossanith, 1995).

During aging, there is a marked increase of hypogonadism and reduction of testosterone secretion associated loss of muscle and bone function, and increased body fat, leading to sarcopenia and frailty (Saad et al., 1995) and this may be contributed to obesity and diabetes (Yeap, 2000; Dhindsa et al., 2018). Senile rat showed decreased testosterone secretion due to the inability of the Leydig cells to respond to luteinizing hormone for testosterone secretion.This may result from mitochondrial dysfunction in managing testosterone production from cAMP production and cholesterol transport via stimulated luteinizing hormone (Wang et al., 2017). 
In infant and juvaniles, milk whey proteins such as alpha-lactalbumin, beta-lactoglobulin, lactoferrin, osteopontin, immunoglobulins, trefoil factors, lactoperoxidase, superoxide dismutase, plateletstimulating factor acetylhydrolase, alkaline phosphatase, and growth factors display prophylaxis and intestinal inflammatory therapy (Chatterton et al., 2013). Whey protein increases the level of total amino acids, essential amino acids (EAA), branch-chained amino acids (BCAA), and leucine in plasma as well as insulin, testosterone, cortisol, or growth hormone (Forbes et al., 2014).

On the other hand, whey products have antioxidant contents (Haraguchi et al., 2011; Zhang et al., 2012). It is rich in amino acid content with high digestibility and antioxidant activity (Giblin et al., 2019; Kareb and Aider, 2019). The antioxidant role of the Whey is due to the chelation of transition metals through lactoferrin and the scavenging of free radicals by its increased sulphur amino acids contents that inhibit lipid peroxidation and generation of peroxide radicals (Chen et al., 2000; Carthy et al., 2015). Vitamines A\&E, cysteine, carotenoids, zinc, selenium, superoxide dismutase, catalase, glutathione peroxidase, milk oligosaccharides and peptides are mainly produced during fermentation and cheese ripening (Imran et al., 2019).

There is a little of work concerned the ageing related changes of male anterior pituitary hormones especially gonadotropin and somatotrophic hormones and the potential therapeutic anti-ageing potential of bovine fresh whey supplementation.

\section{Materials \& Methods \\ Whey syrup supplementations}

Fresh bovine whey syrup was daily obtained from the Faculty of Agriculture, Cheese Fermentation Labe, Mansoura Univ., Egypt. Rats orally supplemented freshly whey every other day for two months.

\section{Whey extracting and investigations:}

Whey was collected from raw buffalo milk after allowing for fermentation and separating the coagulate product for cheese formation and separate the crude syrup. According to Parris and Baginskla (1991), whey protein was determined and SDS-PAGE electrophoresis was conducted (Laemmli et al., 1970). Lactose (Essig and Kleyn, 1983) and total antioxidant contents (Lim and Quah, 2007) were determined in whey syrup. The number of lactobacilli colonies was also estimated (Morelli et al., 1986) (Table 1, Figure 1).

Table1. Bovine whey contents of lactose, protein, antioxidants, lactobacilli and SNF and freezing point.

\begin{tabular}{lc}
\hline \multicolumn{1}{c}{ Item } & Content \\
\hline SNF (standard solid factor) & $9.9 \%$ \\
Lactose $(\mathrm{mg} / \mathrm{mL})$ & 5.5 \\
Total protein(mg/mL) & 3.75 \\
Total antioxidant activity $(\mathrm{mg} / \mathrm{L})$ & 4.7 \\
Freezing point & 0.63 \\
Lactobacilli cell count & $60 / \mathrm{mL}$ \\
\hline
\end{tabular}

\begin{tabular}{|c|c|c|}
\hline Lanes: & \multicolumn{2}{|c|}{ SAMPLE } \\
\hline Bands & KD & $\%$ \\
\hline 1 & 134.35 & 11.1 \\
\hline 2 & 94.985 & 16.5 \\
\hline 3 & 79.874 & 6.62 \\
\hline 4 & 76.76 & 7.1 \\
\hline 5 & 69.102 & 18.9 \\
\hline 6 & 62.494 & 2.29 \\
\hline 7 & 60.822 & 10.5 \\
\hline 8 & 59.078 & 12.9 \\
\hline 9 & 47.184 & 14.1 \\
\hline Sum & & 100 \\
\hline In Lane & & 100 \\
\hline
\end{tabular}

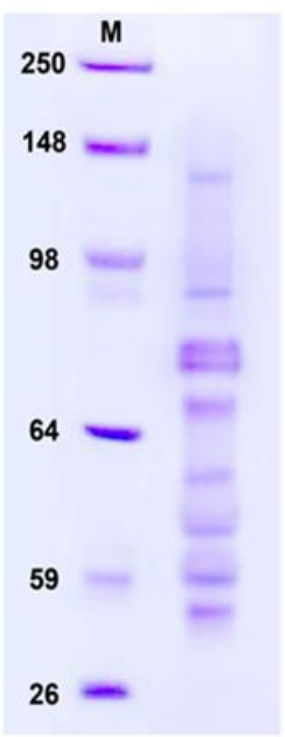

Figure 1. SDS-PAGE analysis of whey showing different protein bands reflecting varieties of nutrient fractions of whey. 


\section{Animal work and Ethical considerations}

Thirty-two male Wister albino rats (Rattus novergicus) at 8 and 30-M (months) old were obtained from Hellwan Breeding Farm, Ministry of Health, Cairo, Egypt, and. They were acclimatized and kept in an aerated room with nearly 12 hour of light and dark cycle and light intensity exposure at 180-200 1x. Free excess of standard diet and water were allowed ad libitum.

This study was carried out with the guidelines of the National Institute of Health recommendations for the use of laboratory animals (NIH Publication No, 8523, revised 1996) and approved by the local Experimental Animal Ethical Committee of Mansoura University, Egypt.

\section{Experimental work}

The rats were categorized according to age into two main groups; 8 months and 30 months old. Each group was further subdivided into two groups, nonwhey supplemented (control) and whey supplemented groups (8 equal for both ages). For whey supplementation, the adult and senile rats are supplied free oral administration whey syrup every other day for two months. The animal groups were then fastened overnight, euthanized by intraperitoneal injection of ketamine $(40 \mathrm{mg} / \mathrm{kg})$, euthanized and dissected. The pituitary glands were dissectede and fixed in phosphate buffered $2 \%$ glutaraldehyde, followed by post-fixation in $1 \%$ osmium tetraoxide, dehydrated in ascending concentrations of ethyl alcohol, cleared in acetone and embedded in epoxy-resin. Ultrathin sections were cut on a LKB Ultratome IV (LKB Instruments, Bromma, Sweden), mounted on grids, stained with uranyl acetate and lead citrate, and examined under a Joel 100CX transmission electron microscope at Mansoura University Lab (Musashino 3-chome, Akishima, Tokyo 196-8558, Japan).

\section{RESULTS}

Whey supplementation to adult rat maintained the normal cytological of gonadotroph cell surrounded by numerous blood capillaries. Thin peripheral marginated heterochromatin aligned on the nuclear envelope, meanwhile bulk of the nucleoplasm is enclosed by euchromatin. Electron-dense secretory granules of varying sizes filled almost the cytoplasm. Also, the somatotrophic cells had characteristic nuclei with irregular nuclear envelope and nuclei rich of euchromatin. The cytoplasm is rich in mitochondria, rough endoplasmic reticulum. Finely homogenous secretory granules are fill almost the cytoplasm. Other cell types are identified such as corticotroph cells which appeared elongated with eccentric nuclei. Granulated endoplasmic reticulum, polysomes and mitochondria are observed (Fig.2 A-A5).
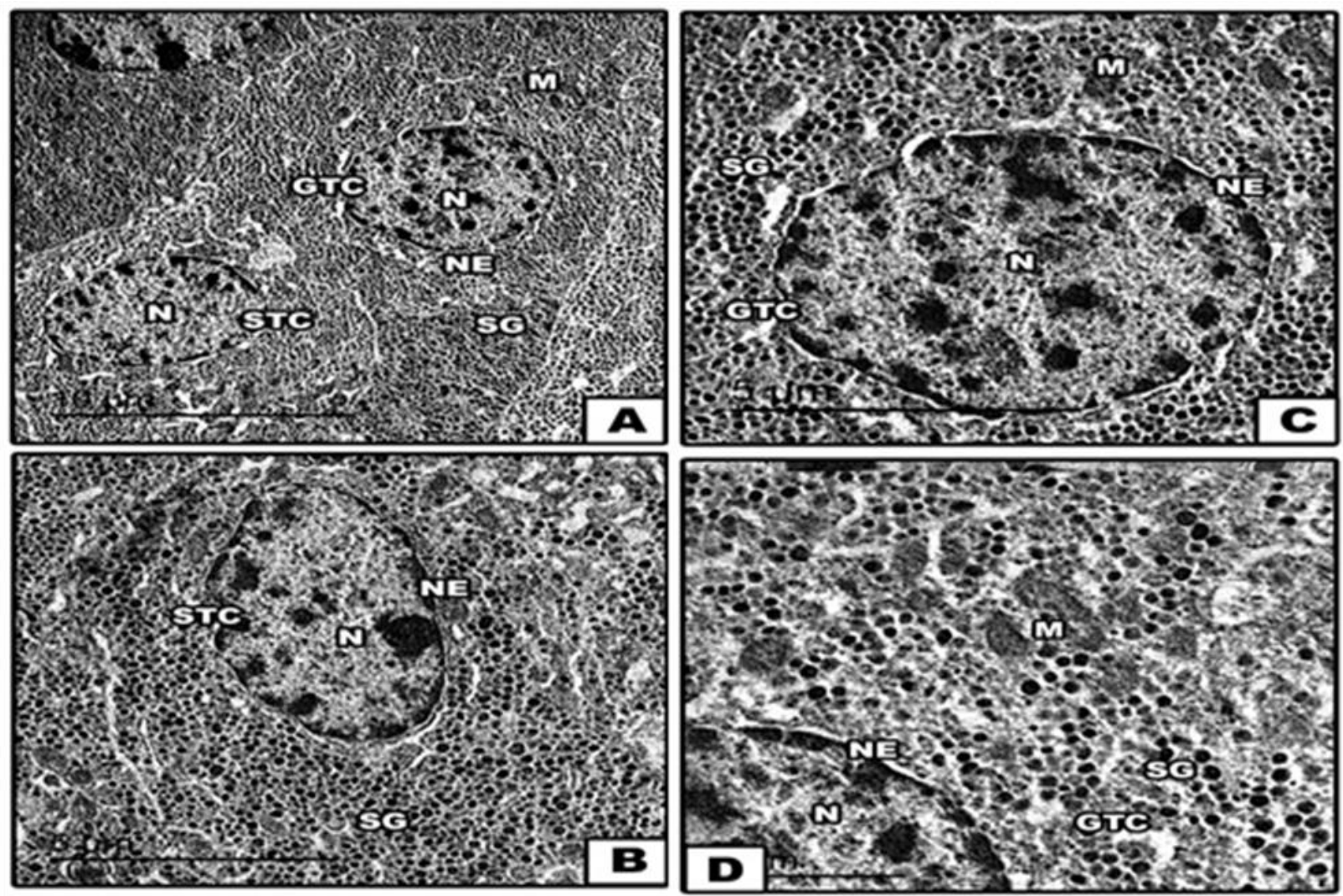

Figure (2). Transmission electron micrographs of the anterior lobe of the pituitary gland of 8 month old rat. A-B. Showing normal somatotrophs abundant with secretory granules, normal nucleus and nuclear envelope, normal mitochondria. C - D. Showing normal gonadotrophs abundant with secretory granules, normal nucleus and nuclear envelope, normal mitochondria. Abbreviations; GTC, gonadotropic cell; M, mitochondria; N, nucleus; NE, nuclear envelope; SG, secretory granules; STC, somatotropic cell. 
Compared to the control group (Figure 6), senile rats showed comparative reduction of the secretory granules within the gonadotroph and somatotroph cells associated with intra and extra cytoplasmic deposits of lipid droplets. Also, there was a comparative increase of the pyknotic nuclei having condensed heterochromatin, convoluted nuclear envelope. Their cytoplasm possessed damaged and atrophied mitochondria. However, whey supplementations improved the cytological structure of gonadotrophs and somatotrophs. They possess abundant secretory granules, decrease lipid droplets accumulation and normal structure and distribution of mitochondria and nuclear chromatin. Also, there is no indication of deposited lipid droplets in the surrounding tissues (Figures 3 \&4).
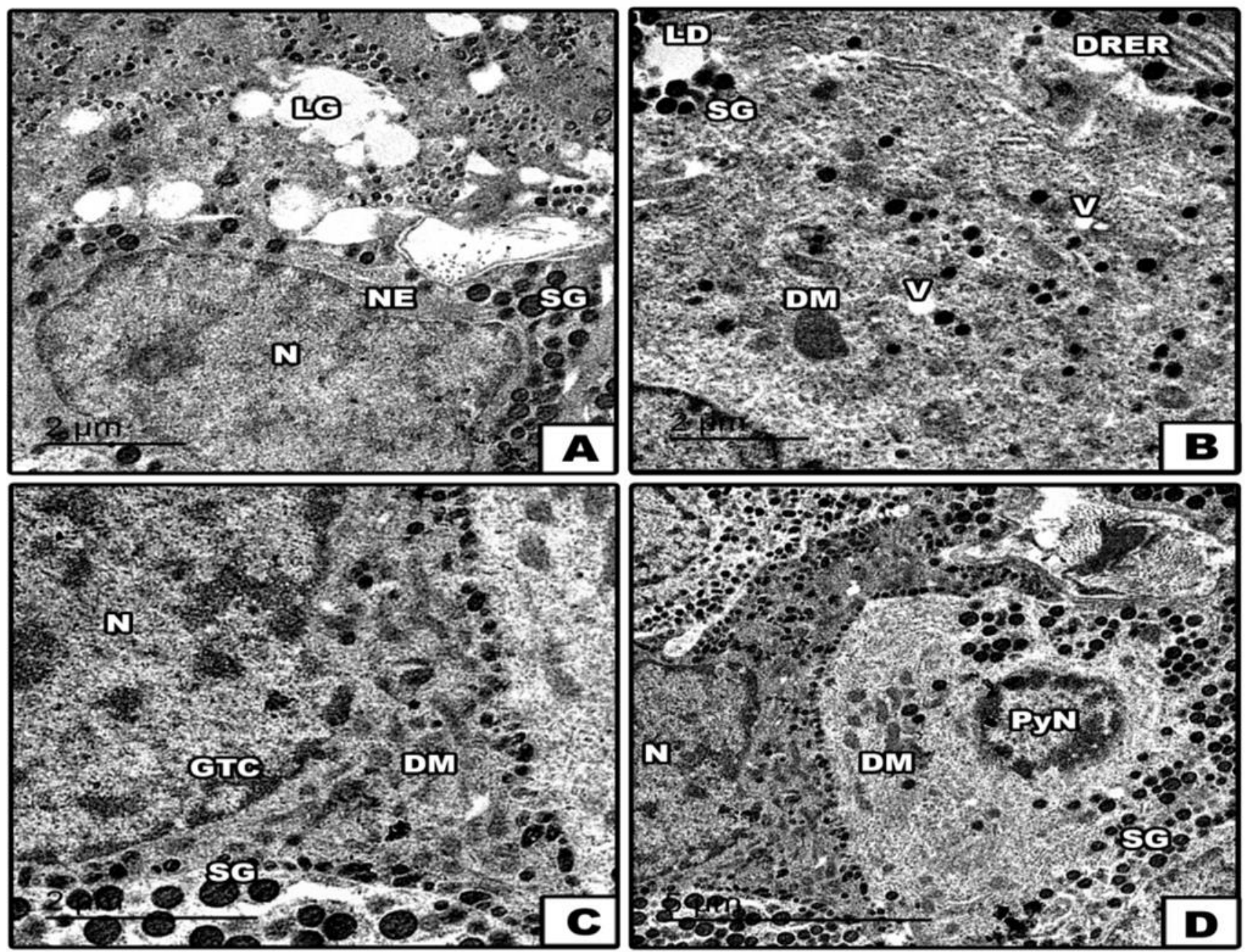

Figure (3). Transmission electron micrographs of the anterior pituitary gland of 30 month old rats. A. Showing somatotrophs surrounded by lipid droplets and lipid granules with decrease in secretory granules. B, C and D. Showing gonadotrophs with pyknotic nuclei, degenerated mitochondria, dilated rough endoplasmic reticulum and decrease in secretory granules.

Abbreviations; DM, degenerated mitochondria; DRER, dilated rough endoplasmic reticulum; GTC, gonadotropic cell; LD, lipid droplets; LG, lipid granules; N, nucleus; NE, nuclear envelope; PyN, pyknotic nuclei; SG, secretory granules; STC, somatotropic cell; V, vacuoles. 



Figure (4). Transmission electron micrographs of anterior pituitary gland of 30 month old rat supplemented whey. A-C.

Showing somatotropic cells with abundant secretory granules, normal nucleus with nuclear envelope, nuclei, mitochondria and decrease in lipid granules. B-D. Showing gonadotrophs abundant with secretory granules, normal nucleus with nuclear envelope and mitochondria. Abbreviations; GTC, gonadotropic cell; N, nucleus; NE, nuclear envelope; $\mathrm{Nu}$, nuclei; $\mathrm{SG}$, secretory granules; STC, somatotropic cells.

\section{DisCUSSION}

The observed degranulation of the secretory granules in somatotroph and gonadotroph cells in the adenohypophysis may be influenced in reduction of the secretion of growth hormone, testosterone, luteinizing hormone and both follicle stimulating hormone.

It is known that the hypothalamus secretes gonadotrophin releasing hormone, which stimulates the anterior pituitary to release luteinizing hormone (LH) and follicle stimulating hormone (FSH). LH enhances Leydig cells to synthesized pregnenolone from cholesterol and consequently testosterone. Sertoli cells is also plays an important role in testosterone production (Strivasa, 2005). According to Selvaratnam and Robaire (2016), ageing is involved in reduction the Sertoli and germ cells and this consequently reflected the reduction of the assayed hormone levels.

It is understand that male reproduction is controlled by hypothalamo-hypophyseal testicular axis: Hypothalamic GH, pituitary LH and FSH and the testosterone have been demonstrated to regulate the sexual and spermatogenic activity (Kumar et al., 2014).
Thus, abnormalities or defects in the LH would disrupt the regulatory function of Leydig cells and result in male infertility (Zirkin and Papadopoules, 2018). Whey supplementation improved the secretory structure of pituitary glands especially somatotroph and gonadotroph cells increasing the growth hormone and follicle and luteinizing stimulating hormone and testosterone to some extent compared to aged groups. This seemed to be resulted in enhancement growth of gut microbiota and secretion of insulin growth factor-1 via stimulating secretion of growth hormone (Kraemer et al., 2013; yan and Charles, 2018; belguesmia et al., 2018).

The present findings are consistent with Imran et al. (2019) who mentioned that The whey is rich in cysteine, vitamins A, E, carotenoids, zinc, selenium. This is counteracted the reactive species and minimized oxidative stress (Corrochano et al., 2019). Also, The lactobacilli organism showed high higher antioxidant activities and free radical scavenging activity of whey fractions after 24-hour fermentations (Osuntoki and Korie, 2010). 
The authors finally concluded that fresh bovine whey showed anti-aging properties against oxidative stress affecting pituitary hormonal secreting cells due to antioxidative activity.

\section{Conflict of Interest}

The authors declare that there is no conflict of interest and no financial or commercial support of this work.

\section{REFERENCES}

1. Almeida, S., Rato, L., Sousa, M., Alves, M. G., \& Oliveira, P. F. (2017). Fertility and sperm quality in the aging male. Current pharmaceutical design, 23(30), 4429-4437.

2. Andre, B.A., \& Gary, A.W. (2011). Endocrinology of the Aging Male. Best Practice and Res. J. Clin. Endocrinol. Metab. 25(2), 303-319.

3. Anisimov, V.N., \& Bartke, A. (2013). The key role of growth hormone-insulin-IGF-1 signaling in aging and cancer. Crit Rev Oncol Hematol. 87(3), 201-223.

4. Ashpole, N. M., Sanders, J. E., Hodges, E. L., Yan, H., \& Sonntag, W. E. (2015). Growth hormone, insulin-like growth factor-1 and the aging brain. Experimental gerontology, 68, 76-81.

5. Belguesmia, Y., Alard, J., Mendil, R., Ravallec, R., Grangette, C., Drider, D., \& Cudennec, B. (2019). In vitro probiotic properties of selected lactobacilli and multi-strain consortium on immune function, gut barrier strengthening and gut hormone secretion. Journal of Functional Foods, 57, 382391.

6. Boguszewski, C. L., Meister, L. H., Zaninelli, D. C., \& Radominski, R. B. (2005). One year of GH replacement therapy with a fixed low-dose regimen improves body composition, bone mineral density and lipid profile of GH-deficient adults. European Journal of Endocrinology, 152(1), 67-75.

7. Chatterton, D. E., Nguyen, D. N., Bering, S. B., \& Sangild, P. T. (2013). Anti-inflammatory mechanisms of bioactive milk proteins in the intestine of newborns. The international journal of biochemistry \& cell biology, 45(8), 1730-1747.

8. Chen, J., Lindmark-Månsson, H., \& Åkesson, B. (2000). Optimisation of a coupled enzymatic assay of glutathione peroxidase activity in bovine milk and whey. International Dairy Journal, 10(5-6), 347-351.

9. Dhindsa, S.S., Irwig, M.S., \& Wyne, K. (2018). Gonadopenia and aging in men. Endocrology Practice 24(4), 375-385.

10. Essig, A.M., \& Kleyn, D.H. (1983). Determination of lactose in milk: comparison of methods. $J$. Assoc. Off. Analytical Chemistery 66(6),15141516.

11. Feldman, H.A., Goldstein, I., Hatzichristou, D.G., Krane, R.J., \& McKinlay, J.B. (1994). Impotence and its medical and psychosocial correlates: results of the Massachusetts male aging study. Journal Urology 151, 54-61.
12. Forbes, S.C., McCargar, L., Jelen, P. \& Bell, G.J. (2014). Dose response of whey protein isolate in addition to a typical mixed meal on blood amino acids and hormonal concentrations. International Journal Sport Nutrition Exercise Metabolism. 24(2), 188-195.

13. Haraguchi, F.K., Silva, M.E., Neves, L.X., Dos Santos, R.C. \& Pedrosa, M.L. (2011). Whey protein precludes lipid and protein oxidation and improves body weight gain in resistance-exercised rats. European Journal Nutrition. 50(5), 331-339.

14. Imran, T.K., Muhammad, N., Muhammad, I., Rahman, U., Muhammad, A.\& Muhammad, H.J. (2019). Antioxidant properties of milk and dairy products: a comprehensive review of the current knowledge. Lipids Health Disease 18: 41.

15. Kareb, O., \& Aïder, M. (2019). Whey and Its derivatives for probiotics, prebiotics, synbiotics, and functional foods: a critical review. Probiotics Antimicrobial Proteins. 2, 345-369.

16. Kraemer, W. J., Solomon-Hill, G., Volk, B. M., Kupchak, B. R., Looney, D. P., Dunn-Lewis, C., ... \& Maresh, C. M. (2013). The effects of soy and whey protein supplementation on acute hormonal responses to resistance exercise in men. Journal of the American College of Nutrition, 32(1), 66-74.

17. Kumar, A., Shekhar, S., \& Dhole, B. (2014). Thyroid and male reproduction. Indian Journal Endocrinology Metabolism 18(1), 23-31.

18. Laemmli, U. K. (1970). Cleavage of structural proteins during the Assembly of the head of Bacteriophage T4. Nature. 227(5259), 680-685.

19. Lim, Y.Y., \& Quah, E.P.L. (2007). Antioxidant properties of different cultivars of Portulaca Oleracea. Food Chemistry 103(3), 734-740.

20. McCarthy, T. L., Kerry, J. P., Kerry, J. F., Lynch, P. B., \& Buckley, D. J. (2001). Evaluation of the antioxidant potential of natural food/plant extracts as compared with synthetic antioxidants and vitamin $\mathrm{E}$ in raw and cooked pork patties. Meat Science, 58(1), 45-52.

21. Morelli, L., Vescovo, M.V., Cocconcelli, P.S., \& Bottazzi, V. (1986). Fast and slow milkcoagulating variants of Lactobacillus helveticus HLM1. Canadian Journal. Microbiology 32, 758760.

22. Moro, T., Tinsley, G., Bianco, A., Marcolin, G., Pacelli, Q.F., Battaglia, G., Palma, A., Gentil, P., Neri, M. \& Paoli, A. (2016). Effects of eight weeks of time-restricted feeding (16/8) on basal metabolism, maximal strength, body composition, inflammation, and cardiovascular risk factors in resistance-trained males. J Transl Med. 14(1), 290.

23. Osuntoki, A., \& Korie, I. (2010). Antioxidant activity of whey from fermented milk. Food Technology Biotechnology. 48(4), 505-511.

24. Parris, S., \& Baginskla, M.A. (1991). Rapid method for the determination of whey protein denaturation. Journal Dairy Science. 74, 58-64. 
25. Rossmanith, W.G. (1995). Gonadotropin secretion during aging in women: review article. Experimental Gerontology 30(3-4), 369381.

26. Saad, F., Röhrig, G., von Haehling, S. \& Traish, A, (2017). Testosterone deficiency and testosterone treatment in older men. Gerontology. 63(2), 144156.

27. Satriyasa, B. (2005). Fraksi heksan dan fraksi methanol ekstrak biji pepaya muda (Carica papaya) dapatmenghambat spermatogonia A mencit jantan (Mus musculus). Journal Veterinary. 11(1), 36-40.

28. Selvaratnam, J.S., \& Robaire, B. (2016). Effects of aging and oxidative stress on spermatozoa of superoxide-dismutase 1 - and catalase-Null mice. Biology Reproduction. 95(3), 60.

29. Speakman, J. R., Talbot, D. A., Selman, C., Snart, S., McLaren, J. S., Redman, P., ... \& Brand, M. D. (2004). Uncoupled and surviving: individual mice with high metabolism have greater mitochondrial uncoupling and live longer. Aging cell, 3(3), 87-95.

30. Veldhuis, J.D., Iranmanesh, A., \& Weltman, A. (1997). Elements in the pathophysiology of diminished growth hormone $(\mathrm{GH})$ secretion in aging humans. Endocrine. 7, 41-48.
31. Wang, Y., Chen, F., Ye, L., Zirkin, B., \& Chen, H. (2017). Steroidogenesis in Leydig cells: effects of aging and environmental factors. Reproduction.154(4):R111-R122.

32. Whey proteins: targets of oxidation, or mediators of redox protection

33. Yan, J., \& Charles, J.F. (2018). Gut microbiota and IGF-1. Calcif Tissue Int. 102(4), 406-414.

34. Yeap, B.B. (2000). Testosterone and ill-health in aging men. National Clinical Practical Endocrinology Metabolism. 9;5(2), 113-121.

35. Yuan, R., Tsaih, S. W., Petkova, S. B., De Evsikova, C. M., Xing, S., Marion, M. A., ... \& Rosen, C. J. (2009). Aging in inbred strains of mice: study design and interim report on median lifespans and circulating IGF1 levels. Aging cell, 8(3), 277-287.

36. Zhang, Q. X., Ling, Y. F., Sun, Z., Zhang, L., Yu, H. X., Kamau, S. M., \& Lu, R. R. (2012). Protective effect of whey protein hydrolysates against hydrogen peroxide-induced oxidative stress on PC12 cells. Biotechnology letters, 34(11), 2001 2006.

37. Zirkin, B.R., \& Papadopoulos, V. (2018). Leydig cells: formation, function, and regulation. Biology of Reproduction. 99(1), 101-111. 